\title{
AKIBAT HUKUM PENGALIHAN HAK ATAS MEREK TERDAFTAR BERDASARKAN AKTA HIBAH WASIAT
}

\author{
Rifzki Dhian Pramuvti, Kholis Roisah \\ Program Studi Magister Kenotariatan, \\ Fakultas Hukum, Universitas Diponegoro
}

\begin{abstract}
The transfer of rights to a trademark is provided in Article 41 paragraph (1) of Law Number 20 of 2016, in which case the right to a registered mark may be transferred or transferred because of a grant of a will, in which case after the transfer of title to the mark takes place, Submission. The transfer of rights to a mark by an authentic deed made by a Public Official or Notary has legal certainty with the anatomy of the deed in accordance with the provisions of Article 38 of Law Number 2 of 2014 concerning Notary Position. Insofar as the contents of the transfer agreement of the grant will not be denied by the parties, the deed shall have the perfect proof power to be used as evidence in the Court. The transfer of Right to Trademark to another person has the consequence that the recipient of the right of a mark shall be obligated to administer and finance the recording of the transfer of rights to the mark officially to the Directorate of Trademark, Directorate General of Intellectual Property, in the event of a transition through the grant, the original owner of the mark shall provide the original certificate Brands and power of attorney to regulate the application for the transfer of rights to the mark.
\end{abstract}

Keywords: Legal Effect, Right of Trademark, Grant of Will

\begin{abstract}
Abstrak
Pengalihan hak atas merek diatur di dalam Pasal 41 ayat (1) UndangUndang Nomor 20 Tahun 2016, yang dalam hal ini hak atas merek terdaftar dapat beralih atau dialihkan karena hibah wasiat yang dalam hal ini setelah pengalihan hak atas merek terjadi, harus diikuti dengan penyerahan. Pengalihan hak atas merek dengan akta otentik yang dibuat oleh Pejabat umum atau Notaris memiliki kepastian hukum dengan anatomi akta yang sesuai dengan sebagaimana diatur didalam pasal 38 Undang-undang Nomor 2 tahun 2014 tentang tentang Jabatan Notaris. Sejauh isi perjanjian pengalihan hibah wasiat tersebut tidak dapat disangkal oleh para pihak, maka akta tersebut memperoleh kekuatan pembuktian yang sempurna untuk dijadikan alat bukti di Pengadilan. Peralihan Hak atas Merek kepada orang lain memiliki konsekuensi bahwa penerima hak merek wajib untuk mengurus dan membiayai pencatatan pengalihan hak atas merek secara resmi ke Direktorat Merek, Direktorat Jendral Hak Kekayaan Intelektual, dengan adanya peralihan melalui hibah wasiat tersebut, maka pemilik awal merek memberikan sertifikat asli merek dan surat kuasa utuk mengatur permohonan penyerahan hak atas merek.
\end{abstract}


Kata kunci Akibat Hukum, Hak Atas Merek, Hibah Wasiat

\section{A. Pendahuluan}

Pada awalnya merek merupakan sebuah tanda dari suatu produk agar konsumen dapat membedakan produk barang atau jasa satu dengan yang lainnya. Merek membuat konsumen lebih mudah untuk mengingat sesuatu yang dibutuhkannya, dengan merek konsumen juga dapat dengan mudah dan cepat dalam menentukan apa yang akan dibelinya. Pandangan masyarakat terhadap sebuah merek bukan hanya dipandang sebagai sebuah tanda ataupun pembeda, namun merek juga telah dipandang sebagai trend gaya hidup masyarakat sebagai tolak ukur pembeda strata sosial dalam tingkat kemampuan ekonomi masyarakat. (Haris, 2009)

Pengertian merek dirumuskan dalam Pasal 1 ayat (1) Undang-Undang Nomor 20 Tahun 2016 tentang Merek, yaitu :

"Merek adalah tanda yang dapat ditampilkan secara grafis berupa gambar, logo, nama, kata, huruf, angka,susunan warna, dalam bentuk 2 (dua) dimensi dan/atau 3 (tiga) dimensi, suara, hologram, atau kombinasi dari 2 (dua) atau lebih unsur tersebut untuk membedakan barang dan/atau jasa yang diproduksi oleh orang atau badan hukum dalam kegiatan perdagangan barang dan/atau jasa.”

Secara khusus, berdasarkan Pasal 41 ayat (1) Undang-Undang Nomor 20 Tahun 2016 tentang Merek dan Indikasi Geografis, hak atas merek terdaftar tersebut dapat beralih atau dialihkan hanya karena hal-hal berikut:

a. Pewarisan;

b. Wasiat;

c. Hibah;

d. Perjanjian; atau

e. Sebab-sebab lain yang dibenarkan oleh Peraturan Perundang-Undangan.

Pengalihan hak atas merek dapat dilaksanakan melalui perjanjian. Terdapat perbedaan antara perjanjian dan perikatan. Pada prinsipnya perikatan adalah sesuatu hubungan hukum antara dua pihak, yang dalam hal ini pihak yang satu berhak menuntut sesuatu hal dari pihak lain dan yang lain berkewajiban 
memenuhi tuntutan tersebut. Perikatan adalah hubungan hukum antara dua orang atau lebih dalam bidang atau lapangan harta kekayaan. Oleh karena itu hubungan tersebut merupakan hubungan hukum.

Pengalihan hak atas merek dapat dibuat dengan perjanjian dibawah tangan maupun dengan akta otentik yang dibuat oleh Pejabat umum atau Notaris, namun dalam Undang-Undang Nomor 20 Tahun 2016 Tentang Merek dan Indikasi Geografis tidak mensyaratkan kewajiban penggunaan akta otentik sehingga dapat dibuat dibawah tangan. Perjanjian dibawah tangan tentu tetap memiliki konsekuensi hukum sejauh perjanjian tersebut tidak disangkal oleh Para Pihak, maka berarti Para Pihak mengakui dan membenarkan apa yang tertulis pada akta di bawah tangan tersebut, sehingga sesuai pasal 1857 Kitab Undang-Undang Hukum Perdata akta di bawah tangan tersebut memperoleh kekuatan pembuktian untuk dijadikan alat bukti di Pengadilan.

Berdasarkan rumusan tersebut di atas, maka dapat diketahui bahwa dalam suatu perikatan terdapat unsur-unsur, antara lain (Muljadi, 2004):

a. Bahwa perikatan itu adalah suatu hubungan hukum;

b. Hubungan hukum tersebut melibatkan dua atau lebih orang atau pihak;

c. Hubungan hukum tersebut adalah hubungan hukum dalam lapangan hukum harta kekayaan;

d. Hubungan hukum tersebut melahirkan kewajiban pada salah satu pihak dalam perikatan dan juga melahirkan hak pada pihak yang satunya lagi.

Sedangkan perjanjian adalah suatu peristiwa yang dalam hal ini seseorang berjanji untuk melaksanakan sesuatu hal. Perjanjian ini akan menimbulkan suatu perikatan antara dua orang yang membuatnya. Dalam bentuknya, perjanjian itu berupa suatu rangkaian perkataan yang mengandung janji-janji atau kesanggupan yang diucapkan atau ditulis. Perjanjian memang sebagai sumber terpenting yang melahirkan perikatan, namun ada sumber lain yaitu undang-undang. Sehingga ada perikatan yang lahir dari perjanjian dan ada perikatan yang lahir dari undangundang.(Muhammad, 1982)

Suatu perjanjian harus memenuhi syarat sahnya perjanjian, yaitu kata sepakat, kecakapan, hal tertentu dan suatu sebab yang halal, sebagaimana ditentukan dalam 
Pasal 1320 Kitab Undang-Undang Hukum Perdata. Terpenuhinya empat syarat sahnya perjanjian tersebut, maka suatu perjanjian menjadi sah dan mengikat secara hukum bagi para pihak yang membuatnya. Salah satunya dapat melalui hibah wasiat. ketentuan pasal 1234 Kitab-Kitab Undang Hukum Perdata ada tiga kemungkinan wujud prestasi, yaitu :

(a) memberikan sesuatu;

(b) berbuat sesuatu;

(c) tidak berbuat sesuatu.

Berdasarkan latar belakang tersebut, maka penulis perlu melakukan penelitian mengenai "Akibat Hukum Pengalihan Hak Atas Merek Terdaftar Berdasarkan Akta Hibah Wasiat".

\section{B. Metode Penelitian}

Metode penelitian yang digunakan adalah yuridis empiris, dengan spesifikasi penelitiannya secara deskriptif analitis. Sumber dan jenis datanya berupa data primer dan data sekunder, lalu teknik pengumpulan data diperoleh melalui studi lapangan dan studi kepustakaan. Teknik analisa datanya menggunakan analisis kualitatif dengan pemikiran secara dedukatif-indukatif.

\section{Hasil dan Pembahasan}

\section{Cara Memperoleh Hak Atas Merek Berdasarkan Pengalihan Hibah Wasiat}

Berdasarkan Pasal 41 ayat (3) Undang-Undang Nomor 20 Tahun 2016 tentang Merek dan Indikasi Geografis, dikatakan bahwa permohonan pengalihan hak atas merek disertai dengan dokumen yang mendukungnya. Pengalihan merek berdasarkan pewarisan, wasiat dan hibah, maka yang harus diperhatikan adalah dokumen-dokumen yang berkaitan dengan bentuk pengalihan itu dikaitkan dengan peristiwa pelepasan hak tersebut dengan berbagai pilihan terhadap kaidah hukum dan akibat hukum yang ditimbulkannya sesuai dengan sifat kaidah hukumnya yang pluralistis tersebut, sedangkan untuk pengalihan melalui sebab-sebab lain yang dibenarkan oleh peraturan perundang-undangan, dokumen yang dimaksud adalah Sertifikat dan bukti lainnya yang mendukung pemilikan hak tersebut. 
Pengalihan merek melalui pewarisan, wasiat dan hibah, maka ketentuan untuk ketiga cara tersebut di Indonesia saat ini masih bersifat pluralisme. Hukum waris, hibah dan wasiat belum ada yang berlaku secara unifikasi, masih berbeda untuk setiap golongan penduduk karena ada yang tunduk kepada hukum adat, ada yang tunduk kepada hukum Islam, dan ada yang tunduk kepada hukum perdata yang termuat dalam Kitab Undang-Undang Hukum Perdata.

Untuk pengalihan melalui perjanjian, karena prinsip hukum perjanjian menganut asas kebebasan berkontrak, maka haruslah diperhatikan syarat-syarat yang harus dipenuhi untuk sahnya suatu perjanjian (Pasal 1320 Kitab UndangUndang Hukum Perdata) dan syarat umum lainnya, sebagaimana yang dimaksud dalam Pasal 1319 Kitab Undang-Undang Hukum Perdata, sedangkan untuk sebabsebab lain yang dibenarkan oleh peraturan perundang-undangan, dalam penjelasan Pasal 41 ayat (1) Undang-Undang Nomor 20 Tahun 2016 dikatakan yang dimaksud dengan sebab-sebab lain yang dibenarkan oleh peraturan perundangundangan adalah sepanjang tidak bertentangan dengan undang-undang ini, misalnya kepemilikan merek karena pembubaran badan hukum yang semua pemilik merek.

Benda bergerak tidak berwujud yang sifatnya dapat dibagi sehingga dapat dialihkan seluruhnya atau sebagian kepada pihak lain. Pengalihan seluruhnya atau sebagian itu ditunjukkan oleh perbuatan yang dilakukan dengan penggunaan hak atas kekayaan intelektual yang diatur dalam KUHPerdata maupun dalam UndangUndang Khusus.

Pengalihan adalah proses, cara, perbuatan mengalihkan pemindahan, penggantian, penukaran, pengubahan. Sedangkan hak adalah kekuasaan untuk berbuat sesuatu (karena telah ditentukan oleh undang-undang, aturan, atau wewenang menurut hukum.

Pengalihan benda bergerak tidak berwujud adalah penyerahan hak kepada pihak lain atau penerima hak dengan cara pewarisan, hibah, wasiat, perjanjian tertulis, atau cara lain yang dibenarkan undang-undang. Menurut Abdulkadir Muhammad undang-undang menganggap benda bergerak tidak berwujud adalah benda bergerak tidak berwujud (intangible movable goods). Meskipun benda 
bergerak tidak berwujud itu benda bergerak, hak tersebut tidak dapat disita (unconfiscable). Alasannya adalah benda bergerak tidak berwujud itu bersifat pribadi dan manunggal dengan diri pemiliknya. Apabila pemilik hak yang berwenang menguasai benda bergerak tidak berwujud dengan haknya itu melakukan pelanggaran hukum, atau mengganggu ketertiban umum, atau bertentangan dengan kesusilaan yang dapat dilarang oleh hukum perbuatan pemilik atau pemegang hak yang menggunakan hak itu. (Badrulzaman, 1983)

Hak atas merek sebagai hak kebendaan tidak berwujud juga dapat beralih atau dialihkan. Ini suatu bukti bahwa Undang-Undang Nomor 20 Tahun 2016 telah mengikuti prinsip-prinsip hukum benda yang dianut oleh seluruh negara di dunia dalam penyusunan undang-undang mereknya.

Sebagai kebendaan immateril, merek harus pula dihormati sebagai hak pribadi pemakainya. Wujud dari penghormatan hak pribadi itu adalah diakuinya oleh undang-undang tentang keberadaan hak milik, apakah itu hak milik atas benda materiil maupun hak milik atas benda immateriil seperti hak merek. Hak milik sebagai hak kebendaan yang paling sempurna tentu saja jika dibandingkan dengan hak kebendaan yang lain memberikan kenikmatan yang sempurna pula kepada pemiliknya. Salah satu wujud pengakuan dari hak kebendaan yang sempurna itu adalah diperkenankannya oleh undang-undang hak kebendaan itu beralih atau dialihkan oleh si pemilik.(Badrulzaman, 1983) Penetuan bahwa akibat hukum tersebut baru berlaku setelah pengalihan hak atas merek dicatat dalam Daftar Umum Merek dimaksudkan untuk memudahkan pengawasan dan mewujudkan kepastian hukum.

Penghibahan dalam sistem Kitab Undang-Undang Hukum Perdata adalah bersifat obligatoir seperti halnya jual-beli dan tukar menukar, hal ini berarti bahwa perjanjian hibah belumlah memindahkan hak milik atas barang yang dihibahkan, hak milik baru perpindah setelah dilakukan penyerahan (levering).

Dalam Pasal 1667 Kitab Undang-Undang Hukum Perdata dikatakan : "Hibah hanyalah dapat mengenai benda-benda yang sudah ada. Jika hibah itu meliputi benda-benda yang baru akan dikemudian hari, maka sekedar mengenai itu hibahnya adalah batal". 
Berdasarkan ketentuan ini, jika suatu barang yang sudah ada dihibahkan bersama-sama dengan suatu barang lain yang baru akan ada dikemudian hari, maka penghibahan mengenai barang pertama adalah sah, tetapi mengenai barang yang kedua tidak sah.

Pasal 1682 Kitab Undang-Undang Hukum Perdata menentukan bahwa suatu penghibahan harus dilakukan dengan akta Notaris, kecuali apa yang menurut Pasal 1678 Kitab Undang-Undang Hukum Perdata, penghibaan dari tangan ke tangan barang-barang bertubuh yang bergerak dan surat-surat piutang yang berbunyi "aan toon der" artinya yang dapat ditagih oleh siapapun juga yang memegang dan memperlihatkan surat itu. Jadi dari ketentuan Pasal 1682 Kitab Undang-Undang Hukum Perdata ini, maka akta Notaris merupakan syarat mutlak untuk sahnya penghibahan bukan saja merupakan suatu alat pembuktian.

Belum ada pengaturan tentang penyerahan (levering) benda bergerak yang terdaftar, namun beberapa doktrin dan analogi pernah dikemukan terkait dengan pengelompokan benda atas kapal. Kapal merupakan benda bergerak yang berwujud, tetapi karena kapal juga merupakan benda terdaftar maka penyerahannya (levering) dilakukan seperti pada benda tidak bergerak yaitu melalui balik nama. Analogi ini juga dapat dipakai untuk hak atas merek sebagai hak atas benda bergerak yang terdaftar sehingga setelah pengalihan terjadi penyerahan hak atas merek tersebut dilakukan dengan balik nama yang diatur secara khusus dalam Undang-Undang Merek.

\section{Akibat Hukum Pengalihan Hak Atas Merek Terdaftar yang Dialihkan Berdasarkan Akta Hibah Wasiat}

Pengalihan hak atas merek dengan akta otentik yang dibuat oleh Pejabat umum atau Notaris memiliki kepastian hukum yang dijamin oleh UndangUndang. Syarat otentik tersebut maka sebuah akta Notaris harus memiliki anatomi akta yang sesuai dengan sebagaimana diatur didalam pasal 38 Undang-undang No. 2 tahun 2014 tentang perubahan atas Undang-undang No 30 tahun 2004 tentang Jabatan Notaris. Sejauh perjanjian tersebut tidak disangkal oleh Para Pihak, maka berarti mengakui dan membenarkan apa yang tertulis pada akta tersebut, sehingga 
akta tersebut memperoleh kekuatan pembuktian yang sempurna untuk dijadikan alat bukti di Pengadilan.

Pembuatan Akta Hibah Wasiat oleh Notaris sesuai struktur pembuatan akta yang diatur dalam Pasal 38 UUJN hanya sebagai kerangka dasar dalam menyusun Akta, berikut bagaimana konsep penyusunan Akta Hibah Wasiat Hak Atas Merek yang dimiliki Agar merek dagang tersebut mendapatkan perlindungan hukum, maka pada tanggal 26 Maret 1998 mengajukan permintaan pendaftaran merek ke Direktur Jenderal Hak Kekayaan Intelektual.

Penghibahan ini dapat dikategorikan kepada perjanjian sepihak sebagai lawan dari perjanjian bertimbal-balik. Perjanjian sepihak menagandung arti bahwa kewajiban memenuhi prestasi hanya dari satu pihak saja sedang pihak lainnya tidak ada kewajiban kontra prestasi. Hal ini dapat terlihat berdasarkan rumusan perjanjian hibah tersebut diatas yang menyebut "dengan cuma-cuma".

Perkataan "di waktu hidupnya" si penghibah dimaksudkan untuk membedakan penghibahan itu dari pemberian-pemberian yang dilakukan dalam suatu surat wasiat (testament), yang dalam hal ini wasiat itu baru akan berlaku sesudah si pemberi meninggal dunia dan setiap saat selama si pembuat wasiat masih hidup dapat menarik atau merobah wasiat tersebut. Penghibahan sebagaimana disebutkan dalam Pasal 1666 Kitab Undang-Undang Hukum Perdata tersebut adalah suatu persetujuan, maka hal itu tidak dapat ditarik kembali secara sepihak oleh si penghibah.(Muhammad, 1990)

Wasiat dalam Kitab Undang-Undang Hukum Perdata terdapat pada Pasal 874, wasiat disebut juga dengan testamen, dalam pasal 874 dapat dipahami bahwa wasiat, yaitu: "Suatu pernyataan dari seseorang tentang apa yang dikehendaki setelahnya ia meninggal."

Berdasarkan asasnya suatu pernyataan yang demikian, adalah keluar dari suatu pihak saja (eenzildig) dan setiap waktu dapat ditarik kembali oleh yang membuatnya. Dengan sendirinya, dapat dimengerti bahwa tidak segala yang dikehendaki oleh seseorang, sebagaimana diletakkan dalam wasiatnya itu, juga diperbolehkan atau dapat dilaksanakan. Pasal 874 BW yang menerangkan tentang 
arti wasiat atau testamen, memang sudah mengandung suatu syarat, bahwa isi pernyataan itu tidak boleh bertentangan dengan undang-undang.

Isi suatu testamen, tidak usah terbatas pada hal-hal yang mengenai kekayaan harta benda saja. Dalam suatu testamen dapat juga dengan sah dilakukan, penunjukan seorang wali untuk anak-anak si meninggal, pengakuan seorang anak yang lahir di luar perkawinan, atau pengangkatan seorang executeurtestamentair, yaitu seorang yang dikuasakan mengawasi dan mengatur pelaksanaan testamen.

Selanjutnya, suatu legaat dapat juga digantungkan pada suatu ketetapan waktu. Menurut bentuknya ada tiga macam testamen, yaitu :

a. Openbar Testament, bentuk ini paling banyak dipakai, yang dalam hal ini orang yang akan meninggalkan warisan dating menghadap pada notaris dengan dihadiri oleh dua orang saksi menyatakan kehendaknya.

b. Oligraphis Testament, suatu bentuk testament yang dibuat/ditulis dengan tangan si pewaris sendiri, yang harus disimpan atau diserahkan kepada notaris, dengan disaksikan oleh dua orang saksi. Sebagai tanggal testament itu berlaku diambil tanggal akte penyerahan. Penyerahan dapat terbuka atau tertutup. Bila tertutup, kelak si pewaris meninggal dunia testament harus diserahkan oleh notaries kepada Balai Harta Peninggalan.

c. Testament Tertutup dan Rahasia, suatu testament rahasia harus selalu tertutup atau disegel dan diserahkan kepada notaris dengan disaksikan oleh 2 (dua) orang saksi.

Pemberi dalam testament menurut BW (Burgerlijk Wetboek) dinamakan hibah wasiat (legaat), yang diatur dalam Hukum Waris, sedangkan penghibah ini adalah suatu perjanjian, maka dengan sendirinya tidak dapat ditarik kembali secara sepihak oleh si penghibah. Dengan demikian Hibah menurut BW (Burgerlijk Wetboek) ada 2 (dua) macam, yaitu: hibah dan hibah wasiat yang ketentuan hibah wasiat sering berlaku pula dalam ketentuan penghibah.

Hibah wasiat merupakan suatu jalan bagi pemilik harta kekayaan semasa hidupnya menyatakan keinginannya yang terakhir tentang pembagian harta peninggalannya kepada ahli waris yang baru akan berlaku setelah si pewaris meninggal dunia. 
Hibah wasiat dapat dibuat oleh pewaris sendiri atau dibuat secara notariil. Yang mana Notaris khusus diundang untuk mendengarkan ucapan terakhir itu dengan disaksikan oleh dua orang saksi, dengan cara demikian maka hibah wasiat memperoleh bentuk akta notaris dan disebut wasiat atau testamen. Pembuatan akta ini Notaris dapat memberikan nasehat kepada pewaris sehingga akta wasiat yang dibuat tidak menyimpang dari aturan - aturan yang telah ditetapkan yang dapat menyebabkan akta tersebut cacat hukum.(Amanat, 2003)

Beralihnya Hak atas Merek kepada orang lain memiliki konsekuensi bahwa pemilik awal merek sudah tidak memiliki lagi hak ekslusif terhadap merek, karena melalui peralihan hak merek melalui hibah wasiat maka yang memiliki hak ekslusif terhadap merek dan yang bersangkutan wajib untuk mengurus dan membiayai pencatatan pengalihan hak atas merek secara resmi ke Direktorat Merek, Direktorat Jendral Hak Kekayaan Intelektual, dengan adanya peralihan melalui hibah wasiat tersebut, maka pemilik awal merek memberikan sertifikat asli merek dan surat kuasa utuk mengatur permohonan penyerahan hak atas merek.

\section{Simpulan}

Pengalihan hak atas merek diatur di dalam Pasal 41 Undang- Undang Nomor 20 Tahun 2016, yang dalam hal ini hak atas merek terdaftar dapat beralih atau dialihkan karena hibah wasiat yang dalam hal ini setelah pengalihan hak atas merek terjadi, harus diikuti dengan penyerahan. Pengalihan hak atas merek dengan akta otentik yang dibuat oleh Pejabat umum atau Notaris memiliki kepastian hukum dengan anatomi akta yang sesuai dengan sebagaimana diatur didalam pasal 38 Undang-undang No. 21 Tahun 2014 tentang tentang Jabatan Notaris. Sejauh isi perjanjian pengalihan hibah wasiat tersebut tidak disangkal oleh para pihak, maka akta tersebut memperoleh kekuatan pembuktian yang sempurna untuk dijadikan alat bukti di Pengadilan.

Beralihnya Hak atas Merek kepada orang lain memiliki konsekuensi bahwa pemilik awal merek sudah tidak memiliki lagi hak ekslusif terhadap merek, karena melalui peralihan hak merek melalui hibah wasiat maka yang memiliki hak 
ekslusif terhadap merek dan yang bersangkutan wajib untuk mengurus dan membiayai pencatatan pengalihan hak atas merek secara resmi ke Direktorat Merek, Direktorat Jendral Hak Kekayaan Intelektual, dengan adanya peralihan melalui hibah wasiat tersebut, maka pemilik awal merek memberikan sertifikat asli merek dan surat kuasa utuk mengatur permohonan penyerahan hak atas merek.

\section{DAFTAR PUSTAKA}

Amanat, A. (2003). Membagi Warisan Berdasarkan Pasal-Pasal Hukum Perdata BW. PT. Raja Grafindo Permai.

Badrulzaman, M. D. (1983). Mencari Sistem Hukum Benda Nasional. Bandung: Alumni.

Haris, M. (2009). Mengenal HAKI, Hak Kekayaan Intelektual Hak Cipta, Paten, Merek, dan Seluk Beluknya. Jakarta: Erlangga Esensi.

Muhammad, A. (1982). Hukum Perikatan. Bandung: Alumni.

Muhammad, A. (1990). Hukum Perdata Indonesia. Jakarta: Citra Aditya Bakti.

Muljadi, K. (2004). Perikatan Pada Umumnya. Jakarta: Rajawali Press. 